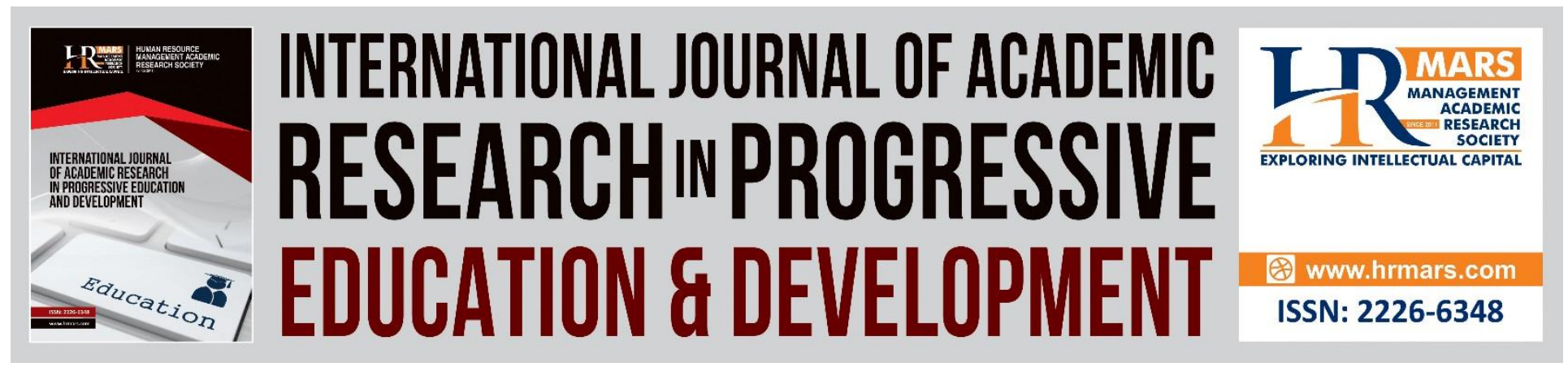

\title{
Exploring the Impact of Internet Accessibility in Implementation of Technology-based Pedagogy for Science in Malaysian Primary Schools
}

Kumutha Krishnamoorthy \& Tuan Mastura Tuan Soh

To Link this Article: http://dx.doi.org/10.6007/IJARPED/v10-i1/9042

DOI:10.6007/IJARPED/v10-i1/9042

Received: 06 December 2020, Revised: 09 January 2021, Accepted: 23 January 2021

Published Online: 16 February 2021

In-Text Citation: (Krishnamoorthy \& Soh, 2021)

To Cite this Article: Krishnamoorthy, K., \& Soh, T. M. T. (2021). Exploring the Impact of Internet Accessibility in Implementation of Technology-based Pedagogy for Science in Malaysian Primary Schools. International Journal of Academic Research in Progressive Education and Development, 10(1), 339-353.

Copyright: (C) 2021 The Author(s)

Published by Human Resource Management Academic Research Society (www.hrmars.com)

This article is published under the Creative Commons Attribution (CC BY 4.0) license. Anyone may reproduce, distribute, translate and create derivative works of this article (for both commercial and non-commercial purposes), subject to full attribution to the original publication and authors. The full terms of this license may be seen

at: http://creativecommons.org/licences/by/4.0/legalcode

Vol. 10(1) 2021, Pg. 339 - 353

http://hrmars.com/index.php/pages/detail/IJARPED

JOURNAL HOMEPAGE

Full Terms \& Conditions of access and use can be found at http://hrmars.com/index.php/pages/detail/publication-ethics 


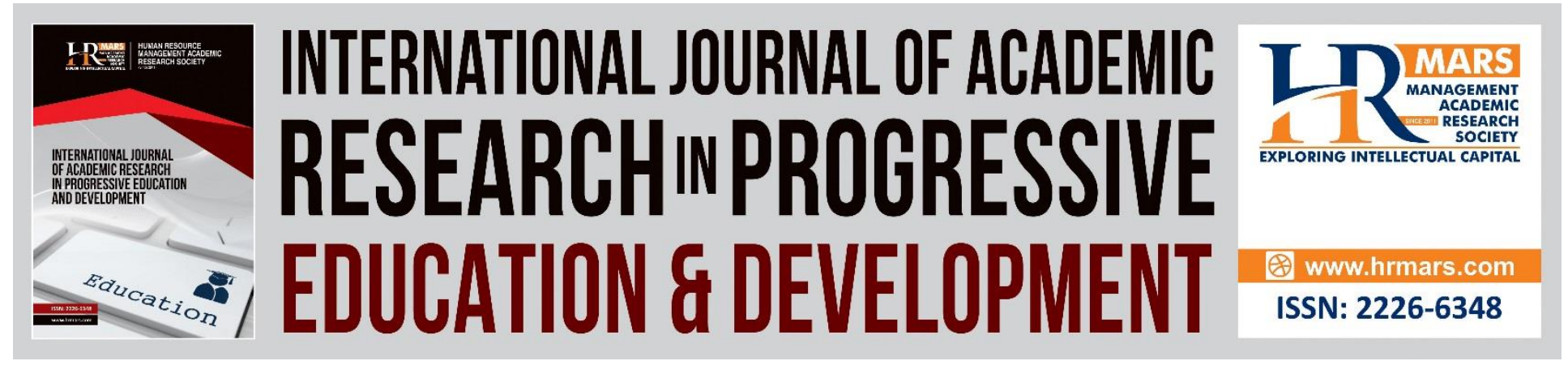

\title{
Exploring the Impact of Internet Accessibility in Implementation of Technology-based Pedagogy for Science in Malaysian Primary Schools
}

\author{
Kumutha Krishnamoorthy \& Tuan Mastura Tuan Soh \\ Universiti Kebangsaan Malaysia, 43600, Bangi, Selangor, Malaysia
}

\begin{abstract}
This review focuses specifically on researches which have been conducted in relation to technology use in the classroom. In specific, the review explores on past studies which investigated the implementation of technology-based pedagogy in primary school science subjects. This review revolves around the impact of internet accessibility on the use of technology to teach science. The review aimed at exploring the extent of internet accessibility that affects the implementation of technology-based Science pedagogy in the classroom. It also aimed to identify the elements of internet accessibility that create effective internet connection for schools to conduct technology-based Science pedagogy. The review also explored the relationship between elements of internet accessibility and the actual implementation of technology-based Science pedagogy in schools. It used a method of reviewing the research articles based on two separate layers which justify the perspectives of teachers and the reality of the internet and the infrastructure in the schools. A total of 42 research papers were reviewed. The review concluded that the core aspects that impact use of technology in teaching science in the classroom are internet speed, connectivity, maintenance of infrastructure and technical support for teachers. The implication of this review is that there is a need to conduct more research in Malaysia that analyses the actual bandwidth in the schools and its impact upon teaching and learning in STEM-related subjects.
\end{abstract}

Keywords: Science, Internet, Technology Based, Access, Pedagogy, Primary Schools

\section{Introduction}

Education was one of the most impacted fields in the world because it encompasses a global transformation in major industries that required a shift in how people are educated. The $21^{\text {st }}$ century education brought an emergence of technology-based education along with exponential changes in pedagogy designing and implementation in the classroom. Technology-based learning is seen as a broad platform to help students achieve more effective levels of learning (Herold, 2016). Since 21st century learning emerged along with the growth of the internet around the 
world it becomes heavily dependent on internet-driven technology too. Technology-based learning is fundamental to today's education because today's education is a system that is shaped according to the fourth industrial revolution (Faulkner \& Latham, 2016). However, the use of technology in education did not begin since the development of the Internet in particular because there has been new use of technology and innovation tools in education prior to the development of Internet technology. Specifically, the trainee teachers in the Sultan Idris Teaching College did participate in a lot of courses that trained them to create and design a wide range of teaching aid technologies like flash cards and three-dimensional models and this somewhat reflects to the continuous progress in educational technology over time (Ying \& Pinang, 1981). Nevertheless, technology-based education has taken a fresh definition with the emergence of $21^{\text {st }}$ century education as education now encompasses planning and management of teaching and learning. In teaching science for example, the ADDIE model (Analyze, Design, Develop, Implement, and Evaluate) and the Dick and Carey model have detailed a complete procedure of how pedagogy should be designed to encourage a more effective level of learning (Gall, Gall, \& Pattanasith, 2019). Serhat Kurt in González dan Quiroz (2019) described these models as instrumental in a more technology-based classroom. There is a clearer definition of how technology-based pedagogy is more related to the actual provision of infrastructure which comprises of technical aspects and skills in Smith (2018). This creates reasonable purpose for the current discussion which seeks to understand the role of the internet as the core of the technology-based education here in Malaysia. This article explores further on the technical factors and elements that drive science teachers in primary schools to design and implement technology-based pedagogy.

Internet access in schools have long been focused when discussing modern-day educational issues around the world and the core availability of the appropriate infrastructure for internet connection has always been a driving factor in education (Almasi, Machumu, \& Zhu, 2017; Madida, Naidoo, \&Rugbeer, 2019). In a study by Pierce and Cleary (2016), educational management was found to be related to technology management and relied heavily on access and connection of the internet as well as training of personnel to maintain and manage internet facilities in schools. Handayani et. al (2019) acknowledge the reality that teaching science to primary school learners is more than just providing facts because science pedagogy now is more related to the inculcation of skills which require learners to directly engage with a multitude of sources which are heavily dependent on the internet (Ambotang, 2019). Therefore, there is a gap that needs to address how the internet access affects the technology-based pedagogy in teaching and learning of science subjects. This review study aims to explore the available literature that represents the argument that internet access is a factor that drives technology-based education. 
Vol. 10, No. 1, 2021, E-ISSN: 2226-6348 @ 2021 HRMARS

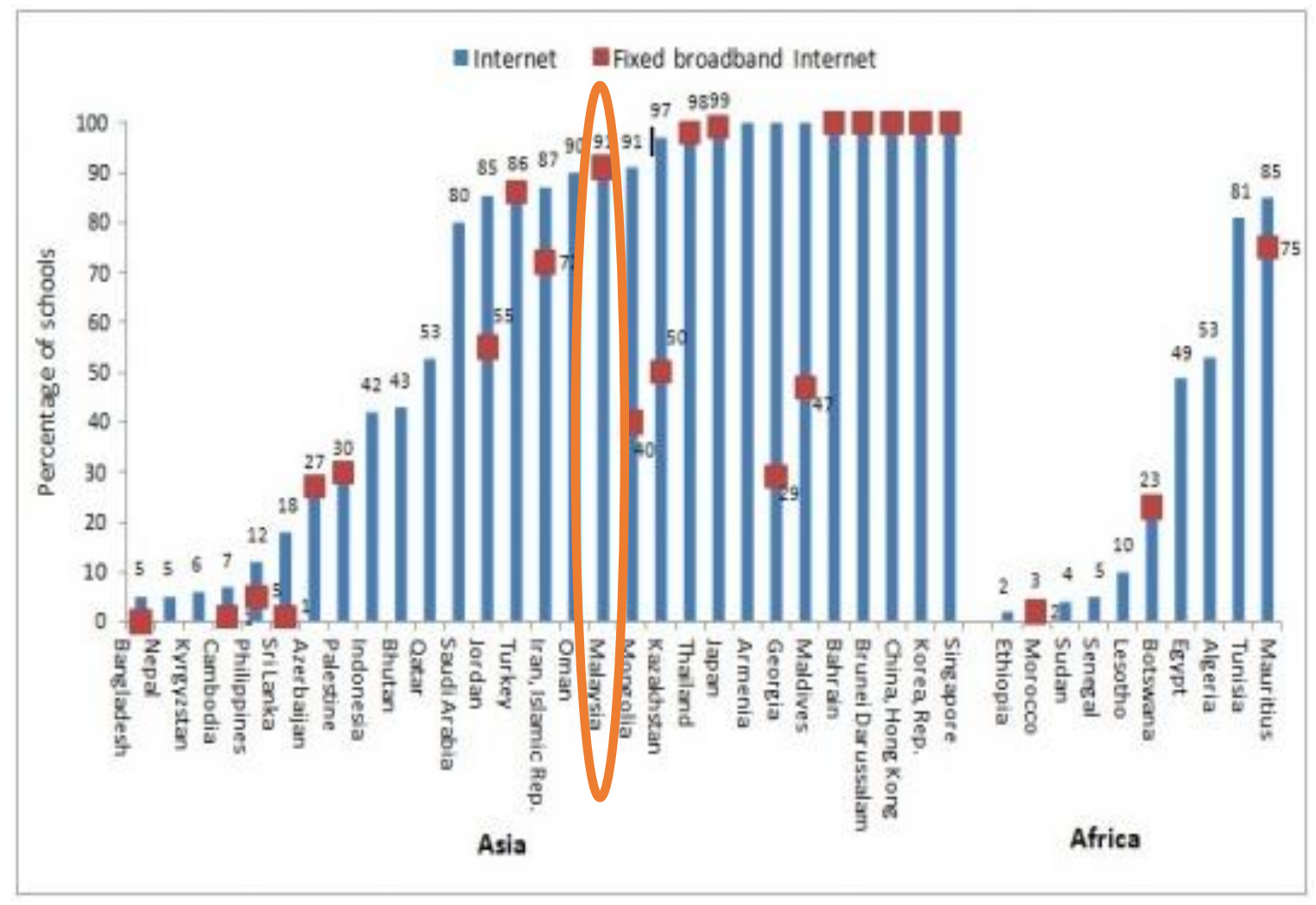

Graph 1: Statistic (UIS)

These data on school connectivity come from regional data collection initiatives led by the UNESCO Institute for Statistics (UIS) in 2014 and done by various partners (past EduTech blog posts have looked at results from these sorts of efforts in the Arab States, Asia, Europe and Latin America). The UIS, which authored the section of the WSIS Targets Review that addresses school connectivity, is careful to note that, "The indicator measures the overall level of access to Internet in schools, not the intensity of use nor the actual amount of time that learners spend on the Internet for educational purposes." Indeed, just because a school is 'connected', this does mean that this connectivity is utilized, let alone utilized well, or used widely, or is sufficient. And: Even if all of these conditions are met, it may be the case that connectivity outside of school is as important, or even more important, for learning as what is available for students within schools.

\section{Problem Statement}

The major problem with internet access in the Malaysian context is the lack of awareness among educators and administrators that internet access is an auxiliary tool that supports teaching and learning significantly (Hashim, Ibrahim, \& Mohamad, 2017). In a report in a local daily by Saad (2017), the MoE has successfully ensured that 8185 schools in Malaysia have internet connections but the issue of bandwidth and internet speed is still a major challenge.Latef, Sharina, Frohlich, Calic, and Muhammad (2018) described internet access as the prominent factor that allows successful teaching and learning of different aspects. Tajuddin and Rohman (2018) provide a deeper enlightenment of the predicament when they embarked on a study that explored the broadband internet services in Malaysian schools according to states and its 
relationship to the performance of students in respective schools. They admitted that a significant lack of scientific research in bandwidth speed in Malaysia continues to challenge the robustness of studies related to internet speed in schools and its impact on teaching and learning. The $21^{\text {st }}$ century science classroom as stated by Aziz and Rahman (2017) is a stage that needs to guide learners to explore and experiment actively and the internet plays a major role. The lack of researches that document the internet bandwidth speed in schools in Malaysia is a major gap that needs to be addressed.

The emergence of technology in education in Malaysia goes back to the late 90s when pilot projects for smart schools were first proposed and with the announcement of the Multimedia Super Corridor (MSC), the birth of a new era in Malaysia was ushered in (Banerjee, 2018). Mirzajani and Bayekolaei (2016) described how the MSC gave birth to the concept of smart schools and how it encouraged the Ministry of Education to draft out a proposal for smart schools. In 1996, the smart schools project was launched as a premier application of the MSC in Malaysia and it created a major paradigm shift in how teaching and learning was conducted in schools. Rauf and Jabeen (2019) elaborate on how the smart school project transformed traditional pedagogy in the classroom and created new demands in the teaching sectors for technical skills and managers of the internet learning scenario. Although there were conflicts in defining the roles of smart schools as schools which implement pedagogy that supports critical thinking and creativity, there were no denials in accepting the fact that smart schools needed the technology and internet to succeed (Lee \& Thah, 2016).

Razali, Bahador, and Saidon (2017) who studied the use of the Frog Virtual Learning Environment in schools in Malaysia found that factors that influenced the use of the virtual learning platform included the aspects related to technicalities such as internet connectivity and access. Although the MoE (2017) reports that all schools in Malaysia have internet access by the year 2013, the problem about varying internet speeds, bandwidth factors and loading times are rarely discussed (Razali et al., 2017). This review is a more intensified effort in understanding how the internet speed factor drives accessibility which in return encourages technology-based science pedagogy in primary schools in Malaysia. Wilson (2018) defined internet accessibility in education as the connectivity that must comprise appropriate speed and usability which also includes physical factors such as number of modems and maintenance of those modems.

Specifically, this review is motivated to understand the challenges faced by science teachers in implementing lessons which are more technologically inclined to give their learners the ability to develop critical thinking skills. The problem with internet connection is obvious when many schools still continue to report low engagement via Google Classroom portals and virtual learning platforms prepared by the ministry. Cheok, Wong, Ayub, and Mahmud (2017) argue that this situation occurs in Malaysian schools because teachers are facing the overarching challenge of conducting lessons against a narrow time frame and the slow internet discourages them. For example, when a science teacher needs to use an online source to demonstrate an experiment to learners, the loading time with a slow internet connection may deter the teacher's intentions. The core principle of an internet-based platform like VLE is the ease of use and when the internet is not supporting the ease of use of the VLE, teachers have no choice but to avoid a technology-based lesson (Shen et al., 2017). It is important to understand the elements in 
technology-based education to answer the questions about the lack of technology-based lessons in science classrooms.

The review addresses the issues as stated in numerous past researches such as Hew and Kadir (2016) who discovered that the use of web-based learning in Malaysia is still low because it is hampered by low quality internet connections in schools. Further explorations by Cheok et al. (2017) indicate that there needs to be more studies in terms of bandwidth in schools and how loading or overloading causes schools in certain areas to experience such bad internet connections. These studies claim that internet connections although available in schools in Malaysia, they are not suitable for high quality $21^{\text {st }}$ century education in the classroom. In general, the higher order thinking skills which needs to be significantly integrated through science in the $21^{\text {st }}$ century context is heavily dependent on a pedagogy that can encourage the learner to explore beyond the classroom (Sulaiman et al., 2017). The aim of the review is to explore more literature related to the current issue and discover more comprehensive answers to the dilemmas faced by science subject teachers in Malaysia.

\section{Research Objectives}

The aim of this review is to provide more comprehensive insights into the issues and challenges of creating a technology-based science lesson. The review comprises overviews of past studies which provide deeper information on the role of internet accessibility as a determinant of technology-based pedagogy. The conceptual paper also aims to shed more light on the core theories and concepts related to the use of internet and internet-based education that will allow more understanding of the issue.

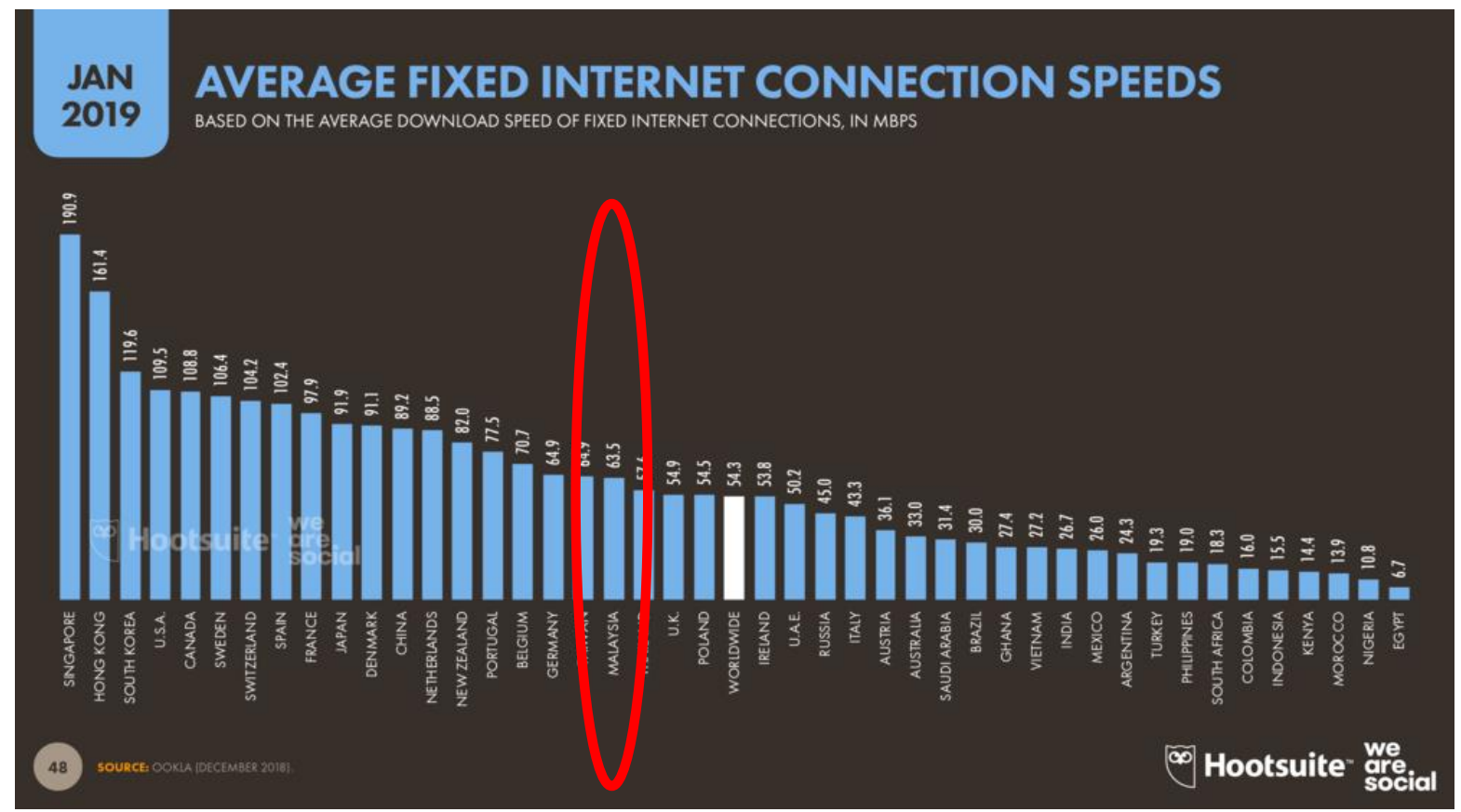

Graph 2: Digital 2019 Reports

According to Digital 2019 Reports, Singapore enjoys the fastest average connections in the world at almost 191MBPS - that's more than 50 times faster than the average connection in Venezuela 
at the other end of the spectrum. Iceland tops the mobile connection speed rankings, which may be one of the reasons why the country holds joint-first place in this year's global internet penetration rankings. And the data only shows that Malaysia only has $63.5 \%$ average fixed internet connection speeds. This reveals the issue at hand which is the stability and speed of internet in Malaysian schools.

\section{Research Questions}

The current review is driven by the following questions:

a. To what extent does internet accessibility affect the implementation of technology-based Science pedagogy in the classroom?

b. What are the elements of internet accessibility that create effective internet connection for schools to conduct technology-based Science pedagogy?

\section{Methodology}

There are two different layers of understanding this problem which is the perspective of teachers towards the use of technology and the actual situation in schools. This situation comprises the actual internet connection status of these schools. This review study was conducted by analysing past studies at two different levels. The first part is a review based on the theoretical aspects which provides a more comprehensive understanding of the concept of technology-based education for science subjects. The second part is grounded in the previous studies conducted by researchers especially within the area of teaching and learning of science in primary schools.

\section{Research Design and Publication Source}

The examination revolved around analysing various papers which have been published. The review focused on research papers related to TPACK, STEM-education and integration of technology in Science classrooms. Most sources were research based related to factors that influence teachers use of technology in the classrooms. Some researches focused on the confidence and technical skills of teachers in the different areas of organising, managing, and conducting technology-based lessons. Meanwhile, the review also included major studies related to the application technology acceptance theories to analyse the further influence of elements in the usage of educational technology. In exploring past studies, most sources were based on international studies.

\section{Study Participants}

Most of the research reviews involved teacher participants. Some papers indicated that the participants are lecturers or educators at higher learning institutes. Several papers also indicated the use of students as participants. A total of 19 papers indicated the use of lecturers and teachers as participants while 23 research publications showed the use of students as participants. 


\section{Findings}

The review draws closely to a proposed framework by Ali, Uppal, and Gulliver (2018). TIPEC (Technology, Individual, Pedagogical, and Enabling Conditions) framework is a key player in understanding technology acceptance in ensuring technology-based education. It allows more comprehensive analysis of key aspects that affect internet accessibility in schools in relation to pedagogical needs like constructing online lessons, web-based learning, gamification, and teleconferencing (Pham, Kim, Walker, DeNardin \& Le, 2019). For the purpose of this review, the framework has been adopted and modified to include the variables specifically experimented in this review. The main idea as shown in (Figure 1 ) is motivated by a key factor which is known as enabling conditions.

In this model, technology is viewed in four main aspects which are internet speed, interruptions during loading, infrastructure maintenance, and technical support for teachers. A review of Kafyulilo, Fisser, and Voogt (2016) reveal that it is important to understand this model in a way that provides a clearer view of the elements that affect the technology-based pedagogy for Science lessons especially. Cetin's (2016) study indicates that Science teachers have a multitude of dependence on technology as science is an evolving subject and requires more webbased lessons which give learners a more effective learning environment. Although there has been much emphasis about teaching science with the help of technology, there has not been much changes in reality because teachers lack the technological support in various areas (Jen, Yeh, Hsu, Wu, \& Chen, 2016). While Cetin (2016) disapproves teachers lack of knowledge in technology as a primary reason for the lack of use of technology in the classroom, Jen et al. (2016) promptly elaborate that it is instrumental that teachers have skills and knowledge in handling the tools via technology such as gamification and teleconferencing to successfully implement a technology-based education in the classroom.

A science teacher needs to be able to access and utilise a wide variety of resources and recreate learning via tools that encourage collaboration, communication, creativity, and critical thinking (Jen et al., 2016). This is significant in this review as it provides ample evidence into the role played by technology in the science teachers' responsibility to design and implement lessons. Harris and Hofer (2016) add that project-based learning and experimental learning are vital in creating lessons that are in line with the 21st century education principles. In discussing technological pedagogical and content knowledge (TPACK), Agustin, Sinaga, and Rochintaniawati (2018) reaffirm that technological integration among teachers is dependent on multiple factors which also include the teacher'sperspectives towards the many functions of technology in education. This sheds light on the perspectives of the teachers when it comes to implementing technology-based lessons in their classrooms.

On the contrary, the review revolves around the reality, the true situation faced by science teachers in their respective schools and how the situation influences the perspectives and the actual usage of technology. This stems from the problem as stated above which is accompanied by a number of factors as projected in the framework in figure 1. It is important to understand that the internet accessibility plays a prominent role in affecting how teachers utilize technologies for educational purpose. It draws closer to the ideas of the theory of technology acceptance model as it projects the emphasis of other factors that can influence the use of technology. According to Hassan, Muthusamy, Tahir, Talib, Yusof, and Atan (2018) it is very 
important to understand the technology acceptance model to create a more consolidated argument that can justify the challenges teachers face in implementing 21st century education in reality. In accepting technology, one must understand what makes technology appealing and one of it is the internet accessibility which according to Latef et al. (2018) plays a crucial role in impacting how teachers use technology in the classroom.

Anderson and Grönlund (2009) describe the internet speed as the core in the challenges of implementing technology-based education in schools. Internet connection and how stable the internet is in a school determines the direction of implementing Science, Technology, Engineering, and Mathematics (STEM) based education in that school (Owusu, Conner, \&Astall, 2018). A study by Anderson and Grönlund (2009) conclude that teachers find technology integration challenging especially when schools lack technical support in organizing and managing the technological aspects in their schools. This is very important in understanding the reality in schools when discussing the integration of technology as the basis of 21st century education in Malaysia. In reviewing the reality layer, this review also looks into two of the core aspects in the technological acceptance model which are "Perceived Usefulness (PU)" and "Perceived Ease of Use(PEOU)".

According to Lucas and Spitler (1999) the two cores of the technology acceptance model are the "Perceived Usefulness(PU)" and "Perceived Ease of Use(PEOU)" which refer to the use of a certain technology and the convenience of applying a technology for a certain purpose. This provides a solid argument in this review as it provides a perspective to further understand how teachers view the use of technology and it proves that teachers use technology when the technology is functional and convenient to use. If a science teacher takes twenty minutes to load a video for a lesson, then it would be irrelevant to use the internet in the classroom as it will take away too much of the time. Tarhini, Hone, Liu and Tarhini (2016) continue to stress that both the elements "Perceived Usefulness(PU)" and "Perceived Ease of Use(PEOU)" determine the usability of certain technologies like videoconferencing, web-based learning, collaborative learning and Flipped learning. Therefore, the review sums up these two perspectives as a challenge in implementing the technology-based education in schools. 


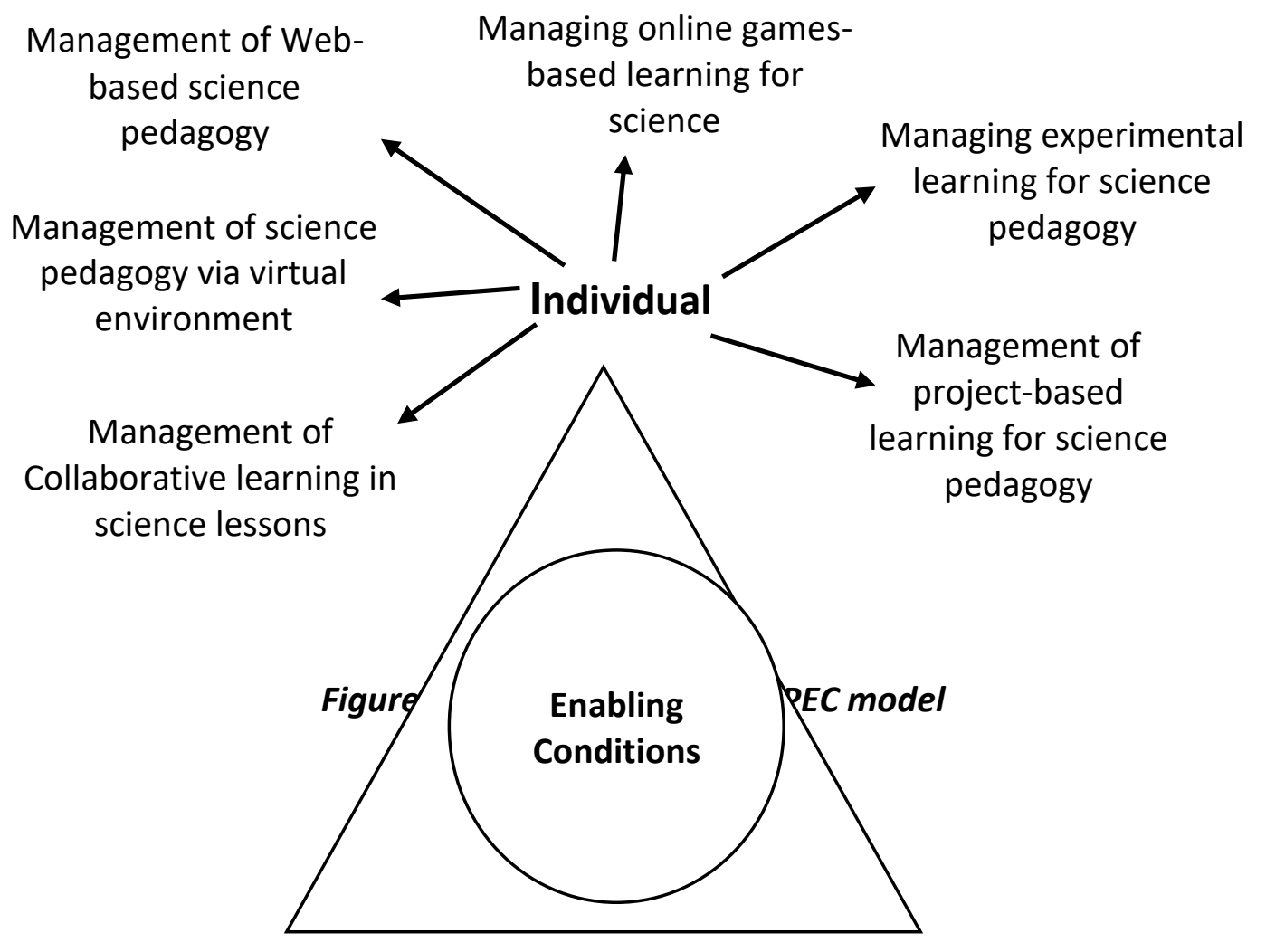

Technology

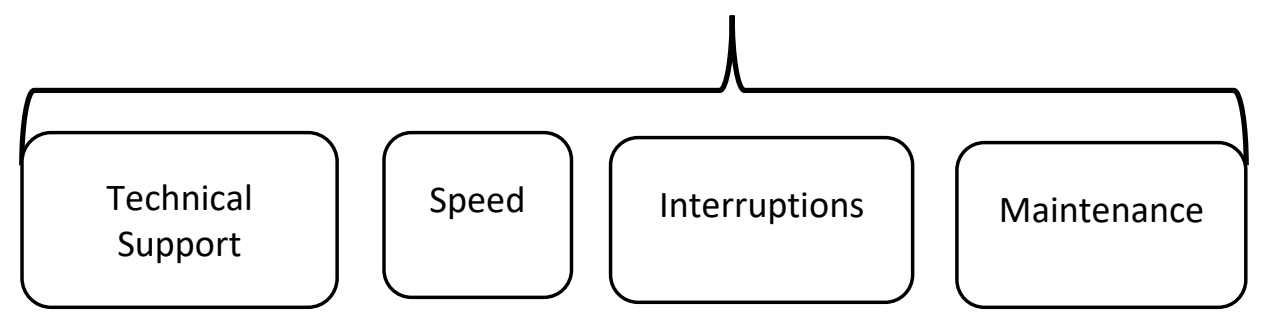

\section{Discussion}

Ahmad, Yoke, Yunos and Amin (2019) conducted a research in higher learning institute in Malaysia to identify the understanding of technology-based pedagogy among lecturers and to investigate the techniques used by the lecherous in their lesson. It is relevant to understand the 
relationship between elements of internet accessibility and the actual implementation of technology-based Science pedagogy in schools. This research is significant in identifying how higher learning in Malaysia is constructed in line with the needs and the demands of the 21st century by utilizing available technology. 142 from a public University were selected to be respondents in this study and participated in a survey. The researchers used an instrument adapted from Hixson, Ravitz and Whisman (2012) whereby the instrument contained items which explored the use of technology in their pedagogy. In this study, an important aspect related to the digital natives in Malaysia was highlighted and the researchers found that respondents lacked the knowledge in managing and utilizing infrastructure related to educational technology. It goes back to the basis of the current review and the problem in the Malaysian educational contexts where educators are finding it increasingly challenging to organize technology-based lessons because of the lack of technical support whether in schools or in higher institutions. Ahmad et al. (2019) found that the use of technology such as videoconferencing or sourcing from the internet in the higher learning institutes are low mainly because lecturers are often challenged by the low quality of the internet and the infrastructure.

Shanmugam and Balakrishnan (2019) offer a more relatable perspective in this review as they studied the application and integration of technology in the teaching and learning in a vernacular school in Perak, Malaysia. This study drew a closer look towards TPACK among the teachers and explored the use of computers by the teachers. It is very important to the current review as it provides a precise direction to understand technology integration in primary school in Malaysia. The mixed method study used a combination quantitative and qualitative methods to provide a more solid argument for the research. In the study, a more relevant picture of this issue is discussed as they explored the influence of internet speed and availability which affected the integration of technology among the teachers. The researchers stated the use of technology and computers in specific, will be increased tremendously with the proper provision and maintenance of internet infrastructure. The connectivity factor drives the use of instructional technology which can increase the efficiency of science lessons in the school. Shanmugam and Balakrishnan (2019) also hold true to the ideas of the TIPEC model and call for more emphasis in improving the quality of the internet service in schools in Malaysia. It supports the questions of the current study which are the extent of internet accessibility that affects the implementation of technology-based Science pedagogy in the classroom and the elements of internet accessibility that create effective internet connection for schools to conduct technology-based Science pedagogy.

In a more intensified study, Razali, Bahador and Saidon (2017) established the relationship between the elements of internet accessibility and the integration of technology in lessons in primary schools. This study in used the Frog VLE platform as a primary data base to explore the usage of different online platforms among teachers in Malaysia. This study used a survey questionnaire as its main instrument and used 66 teachers as respondents. It reports that internet accessibility which comprises of internet speed, maintenance of internet infrastructure and technical support all play primal roles in determining the use of technology in constructing lessons. It helps the current review in a way that it provides more suggestions to improve the internet services in schools in Malaysia. One major concern is technical support when teachers are not equipped to troubleshoot and manage issues such as connectivity and overloading. 
Bandwidth is a very complicated aspect and it requires professional and trained personnel who can work with the problems. Hence, Razali et al. (2017) stresses the need for more scientific researches that document the actual internet speed in schools in Malaysia and come up with more strategies to solve the challenges faced by teachers.

The review also finds Wilson (2018) supportive to the rising needs in studies actually exploring bandwidth in schools to provide a clearer explanation of the issues surrounding the integration of technology in schools. Wilson (2018) who conducted studies across Australia states that the connectivity and availability of internet connections in Australia is still a major challenge in education. It is equivalent to Latefet al. (2018) who also mentioned how Malaysia still has schools in areas which barely have internet connections. Park, Freeman and Middleton (2019) attest to Wilson (2018) as they also find that there needs to be more critical experiments in the internet connectivity in schools to understand the problems of technology integration in education. This is something that goes back to the initial argument in the review that the use of technology in science lessons in primary schools are directly affected by the internet access in schools. It is the primary basis of the current review and these researches have been able to carry a more evidence-based discussion regarding the matter.

\section{Conclusion}

The discussions sum up the core questions in this review and provides a deeper understanding of the main issue. The summary of the review concludes that there needs to be systematic analysis of bandwidth speed in the schools in Malaysia in order to answer the questions in the challenges faced by science teachers. This is because the review discovered that most researches depend on data provided by users and do not always reflect the actual condition of internet-related aspects in the respective schools. Understanding the dilemmas faced by science teachers in primary schools in Malaysia will require more deeper analysis that can project the actual internet speed, loading time, wait time and the problems that stem from lack of technical support and knowledge.

\section{Acknowledgement}

I would like to acknowledge everyone who played a role in my academic accomplishments. First of all my husband and my children who supported me with love and understanding. Without them, I would never have reached this current level of success. Secondly, my supervisor whom has provided advice and guidance throughout the research process. Thirdly I thank my friends whom supported me as well too.

\section{References}

Agustin, R. R., Sinaga, P., \& Rochintaniawati, D. (2018). The investigation of science teachers' experience in integrating digital technology into science teaching. In Journal of Physics: Conference Series (Vol. 1013, No. 1, p. 012079). IOP Publishing.

Ahmad, M., Badusah, J., Mansor, A. Z., Abdul Karim, A., Khalid, F., Daud, M. Y., ... \&Zulkefle, D. F. (2016). The Application of 21st Century ICT Literacy Modelamong Teacher Trainees. Turkish Online Journal of Educational TechnologyTOJET, 15(3), 151-161. 
Ali, S., Uppal, M. A., \& Gulliver, S. R. (2018). A conceptual framework highlighting e-learning implementation barriers. Information Technology \& People.

Almasi, M., Machumu, H., \& Zhu, C. (2017). Internet use among secondary schools students and its effects on their learning. In Proceedings of INTED2017 Conference 6th-8th March.

Ambotang, A. S. (2019). The Effect of Teacher Accountability Level, Teacher Role and Self-Efficacy on the Implementation of 21st Century Primary Education. Malaysian Journal of Social Sciences and Humanities (MJSSH), 4(6), 170-180.

Anderson, A., \&Grönlund, Å. (2009). A conceptual framework for e-learning in developing countries: A critical review of research challenges. The electronic Journal of information systems in developing Countries, 38(1), 1-16.

Aziz, N., \& Rahman, N. A. (2017, July). Use of ICT in indigenous primary school classroom: A case study of teachers' expectations and experiences. In 2017 International Conference on Research and Innovation in Information Systems (ICRIIS) (pp. 1-4). IEEE.

Banerjee, I. (2018). Cultural industries and cultural dynamics in Malaysia: Critical problems of content in the age of infrastructure. JurnalKomunikasi: Malaysian Journal of Communication, 16.

Cetin, N. I. (2016). Effects of a Teacher Professional Development Program on Science Teachers' Views about Using Computers in Teaching and Learning. International journal of environmental and science education, 11(15), 8026-8039.

Cheok, M. L., Wong, S. L., Ayub, A. F., \& Mahmud, R. (2017). Teachers' Perceptions of E-Learning in Malaysian Secondary Schools. Malaysian Online Journal of Educational Technology, 5(2), 20-33.

Faulkner, J., \& Latham, G. (2016). Adventurous lives: Teacher qualities for 21st century learning. Australian Journal of Teacher Education, 41(4), 9.

Gall, N., Gall, J. E., \& Pattanasith, S. (2019). The Blended Training Design Model: an Example of Instructional Model Adaptation. International Journal of the computer, the Internet and Management, 27(1), 1-7.

González, L. F. M., \& Quiroz, V. G. (2019). Instructional Design in Online Education: a Systemic Approach. European Journal of Education, 2(3), 64-73.

Handayani, H., Sopandi, W., Syaodih, E., Suhandi, A., Maftuh, B., Hermita, N., ... \&Samsudin, A. (2019, February). Comprehension of in-service primary-science teachers toward 21st century skills: A case study on Purwakarta. In Journal of Physics: Conference Series (Vol. 1157, No. 4, p. 042130). IOP Publishing.

Harris, J., \& Hofer, M. (2016, March). Planning for deep learning using TPACK-based learning activity types. In Society for Information Technology \& teacher education international conference (pp. 2864-2871). Association for the Advancement of Computing in Education (AACE).

Hashim, N. M., Ibrahim, Y., \& Mohamad, S. (2017). PENILAIAN KESESUAIAN PRASARANA PENDIDIKAN MELALUI PROSES HIRARKI ANALITIK DI KUALA LUMPUR (Suitability Analysis of Education Infrastructure Using AnaliticalHirarchy Processes (AHP) in Kuala Lumpur). eBangi, 8(1).

Hassan, Z., Muthusamy, J., Tahir, L., Talib, R., Yusof, S. M., \& Atan, N. A. (2018, December). The 21st Century Learning in Malaysian Primary School: Exploring Teachers' Understanding 
and Implementation of HOTS. In 1st International Conference on Creativity, Innovation and Technology in Education (IC-CITE 2018). Atlantis Press.

Herold, B. (2016). Technology in education: An overview. Education Week, 20, 129-141.

Hew, T. S., \& Kadir, S. L. S. A. (2016). Understanding cloud-based VLE from the SDT and CET perspectives: Development and validation of a measurement instrument. Computers \& Education, 101, 132-149.

Hixson, N. K., Ravitz, J., \&Whisman, A. (2012). Extended Professional Development in ProjectBased Learning: Impacts on 21st Century Skills Teaching and Student Achievement. Charleston, WV: West Virginia Department of Education. Retrieved from https://www.academia.edu/1999374

Jen, T. H., Yeh, Y. F., Hsu, Y. S., Wu, H. K., \& Chen, K. M. (2016). Science teachers' TPACK-Practical: Standard-setting using an evidence-based approach. Computers \& Education, 95, 45-62.

Kafyulilo, A., Fisser, P., \&Voogt, J. (2016). Factors affecting teachers' continuation of technology use in teaching. Education and Information Technologies, 21(6), 1535-1554.

Latef, A., Sharina, A., Frohlich, D., Calic, J., \& Muhammad, N. H. (2018). Teachers' Perceptions towards Implementing Mobile Learning in Rural Malaysia. In E-proceeding of the 1st international medlit media literacy for social change conference 2018 (pp. 267-284). UMK Press.

Lee, M. N., \&Thah, S. S. (2016). Building and sustaining national ICT/education agencies: Lessons from Malaysia. World Bank.

Lucas, H.C., and V.K. Spitler (1999) "Technology Use and Performance: A Field Study of Broker Workstations" Decision Sciences 30(2), pp.291-311.

Madida, M., Naidoo, G. M., \& Rugbeer, H. (2019). Barriers to effective digital teaching in rural schools. Gender and Behaviour, 17(4), 14101-14115.

Ministry of Education. (2017). Pelanstrategik interim KementerianPelajaran Malaysia 2011-2020. Kuala Lumpur: PercetakanNasionalBerhad.

Mirzajani, H., \& Bayekolaei, M. D. (2016). Smart schools an innovation in education: Malaysian's experience. Asian Journal of Education and Training, 1(2), 11-15.

Owusu, K. A., Conner, L., \& Astall, C. (2018). Contextual influences on science teachers' TPACK levels. In K-12 STEM Education: Breakthroughs in Research and Practice (pp. 448-475). IGI Global.

Park, S., Freeman, J., \& Middleton, C. (2019). Intersections between connectivity and digital inclusion in rural communities. Communication Research and Practice, 5(2), 139-155.

Pham, L., Kim, K., Walker, B., DeNardin, T., \& Le, H. (2019). Development and Validation of an Instrument to Measure Student Perceived E-Learning Service Quality. International Journal of Enterprise Information Systems (IJEIS), 15(2), 15-42.

Rauf, M. B., \&Jabeen, R. (2019). The Role of Education Sector in the Development of Malaysia. Pakistan Journal of International Affairs, 2(1).

Razali, N. Z., Bahador, Z., \&Saidon, M. K. (2017). Faktor-faktor yang mempengaruhipenggunaanvle frog dalamkalangan guru di sekolahmenengah. Proceedings of the ICECRS, 1(1).

Saad, M. M. (2017). Usaha maksimumgunateknologi di sekolah - Mahdzir. https://www.bharian.com.my/node/240231 
Shanmugam, K., \& Balakrishnan, B. (2019). Motivation in Information Communication and Technology-based science learning in Tamil schools. JurnalPendidikan IPA Indonesia, 8(1), 141-152.

Shen, C. M., Zainuddin, N. M. M., Maarop, N., Yaacob, S., Rahim, N. Z. A., \& Hassan, W. A. W. (2017). Design of Frog Virtual Learning Environment (Frog VLE) Aesthetics Model for Malaysia Primary Schools. Open International Journal of Informatics (OIJI), 5(1), 23-31.

Smith, T. I. (2018). Educational Technology Management: Infrastructure and Innovation, a case study from a K-12 private School in Australia.

Sulaiman, T., Muniyan, V., Madhvan, D., Hasan, R., Syrene, S., \& Rahim, A. (2017). Implementation of higher order thinking skills in teaching of science: A case study in Malaysia. International Research Journal of Education and Sciences (IRJES), 1(1), 25502158.

Tajuddin, M. Z. M., \&Rohman, I. (2018, April). The Impact of Broadband Penetration on the Student Performance in Primary and Secondary School in Malaysia. In Proceedings of the 11th International Conference on Theory and Practice of Electronic Governance (pp. 111117).

Tarhini, A., Hone, K., Liu, X., \& Tarhini, T. (2016). Examining the moderating effect of individuallevel cultural values on users' acceptance of E-learning in developing countries: a structural equation modeling of an extended technology acceptance model. Interactive Learning Environments.

Wilson, G. (2018). Get connected: Why connectivity and networking remain a challenge for schools. Education Technology Solutions, (85), 62.

Ying, L. C., \& Pinang, M. P. S. (1981). SejarahPerkembanganLatihanPerguruan di Malaysia: SatuTinjauan. Asia Pacific Journal of Educators and Education, 3(1), 1-11. 